
Mark 0'Brien - 9781526108425 Downloaded from manchesterhive.com at $04 / 26 / 2023$ 12:46:23PM via free access 


\section{The Fourth Estate}

\section{MANCHESTER 1824}

Manchester University Press 
Mark 0'Brien - 9781526108425 Downloaded from manchesterhive.com at $04 / 26 / 2023$ 12:46:23PM via free access 


\title{
The Fourth Estate
}

\author{
Journalism in twentieth-century Ireland
}

\section{Mark O’Brien}

Manchester University Press 
The right of Mark O'Brien to be identified as the author of this work has been asserted by him in accordance with the Copyright, Designs and Patents Act 1988.

Published by Manchester University Press

Altrincham Street, Manchester M1 7JA

www.manchesteruniversitypress.co.uk

British Library Cataloguing-in-Publication Data

A catalogue record for this book is available from the British Library

Library of Congress Cataloging-in-Publication Data applied for

ISBN 9780719096136 hardback

First published 2017

The publisher has no responsibility for the persistence or accuracy of URLs for any external or third-party internet websites referred to in this book, and does not guarantee that any content on such websites is, or will remain, accurate or appropriate.

Typeset by Out of House Publishing 